\title{
The Association of Advanced Math Course-Taking by American Youth on Subsequent Receipt of Public Assistance
}

\author{
Kerry Adzima
}

\begin{abstract}
Helping people move to independence is often cited as a primary goal of public assistance policies in the United States. Over the past several decades, welfare reform efforts in the US have promoted the idea of a work-first approach. Research shows that this approach has discouraged or at least made it harder for some students to attend college while meeting the work requirements for aid. How can those students who need public assistance increase their chances of finding a sustainable job and thus not need to rely on the public support system after high school? To address this question, this study used a sample of 3,384 student responses from the National Longitudinal Study of Adolescent to Adult Health and a recursive bivariate probit model to analyze the association between advanced math course-taking in high school and the probability of subsequent receipt of public assistance. The empirical results suggest that taking advanced math courses in high school is associated with a lower probability of receiving public assistance for recent graduates. These findings are particularly important for school social workers who work in conjunction with teachers and school counselors to help at-risk students improve their chances of future financial independence.
\end{abstract}

Keywords: Income support, public assistance, advanced mathematics, work-first

The call to address challenges in both the K-12 educational system as well as the income support system in the United States in the 1980s and 1990s continues to provoke debates decades later. Additionally, the criticisms of past and current policy reforms remain a critical talking point for many U.S. politicians. In terms of education, the seminal report published by the Reagan administration in 1983, A Nation at Risk, claimed that American schools were failing (National Commission on Excellence in Education, 1983). The commissioned authors suggested that schools needed to adopt more rigorous and measurable standards for learning. The findings from this report ignited a wave of educational reform efforts. For example, education reform in the 1980s is best known for changing the educational landscape from a focus on inputs to a focus on outputs or student achievement (K12 Academics, 2004). In the 1990s most states adopted an outcome-based educational approach (Hamilton et al., 2008). This led to state committees adopting standards and then choosing appropriate quantitative assessments to measure student progress in meeting those standards. The standards-based movement resulted in the No Child Left Behind Act of 2001 which required states to develop assessments in basic skills in order to receive federal funding. More recently, the Common Core State Standards Initiative, sponsored by the National Governors Association (NGA) and the Council of Chief State School Officers (CCSSO), has created educational standards in English, language arts, and mathematics with the intent of ensuring that all students graduating from high school are prepared to enter college programs or the workforce (Common Core State Standards, 2020). Finally, the most recent piece of legislation known as the Strengthening

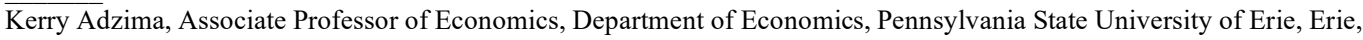
PA.

Copyright (C) 2020 Authors, Vol. 20 No. 3 (Fall 2020), 739-755, DOI: 10.18060/23866

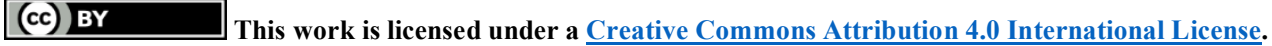


Career and Technical Education for the $21^{\text {st }}$ Century Act, showcases the current administration's focus on workforce development (Ujifusa, 2018).

The income support system in the United States has also been at the forefront of many political debates since at least the 1970s when the federal government began expanding benefits to working families. In addition to the Earned Income Tax Credit enacted in 1975, benefits to working adults also included the child tax credit, food stamps, health insurance, and state income supplement programs (Sawhill \& Haskin, 2002). Many argue that Ronald Reagan's 1976 presidential campaign brought negative attention to the public assistance system, leading many U.S. citizens to believe that the system catered to people who did not want to work and who were fraudulently receiving benefits. In 1980, the Reagan administration cut public assistance spending and gave states the option of requiring income support recipients to participate in workforce training programs.

The next major reform to the income support system came about under former U.S. President Bill Clinton who promised to "end welfare as we know it" during his run for presidency (Semuels, 2016, para. 3). In 1996, Clinton signed into law the Personal Responsibility and Work Opportunity Reconciliation Act (PRWORA), ending the federal guarantee of assistance for needy families, and further promoting a work-based system of supports (1996, Pub. L. No. 104-193). The act also replaced the federal assistance program known as Aid to Families with Dependent Children (AFDC) with the Temporary Assistance for Needy Families (TANF) program which provides block grants to states. TANF added work requirements for aid, set caps on how long and how much aid a person could receive, and decreased the number of adults eligible for benefits (Center on Budget and Policy Priorities, 2020).

With a booming U.S. economy in the late 1990s, there was a somewhat decreased focus on welfare reform as states continued implementing the work-first strategies encouraged by the PRWORA. In addition, statistics showed that in the years immediately following the change to TANF, the number of income support recipients went down dramatically from 5 million families in 1994 to 2.2 million families in 2000 and the labor force participation rate among low-income single-parent families was also shown to grow dramatically (Greenberg, 2001). However, researchers were quick to claim that many former public assistance recipients who took low-wage jobs were not better off financially once the cost of commuting, health insurance, and child care were taken into account (Brauner \& Loprest, 1999; Hays, 2003; Loprest, 1999; Peterson et al., 2002). About a decade later, in the aftermath of the Financial Crisis and Great Recession, studies showed that roughly 52 million people or about one in five Americans were receiving some form of government assistance and once again welfare reform resurfaced as a topic of major concern (United States Census Bureau, 2015).

Coincidentally, even before the Great Recession, which began in December 2007 and lasted until June 2009, researchers were starting to question whether the work-first approach actually promoted long-term self-sufficiency. For example, Hotz et al. (2006) compared a human capital development approach to welfare reform which emphasizes education and vocational training programs to a labor force attachment (LFA) approach which emphasizes getting public assistance recipients into jobs quickly to help develop 
their skills. The results of this study disproved earlier findings from California's Greater Avenues to Independence (GAIN) program which claimed that a work-first approach is more sustainable. Instead, the authors concluded that an educational approach is more effective in the long-run. In a related study, Jacobs and Winslow (2003) reported that "the long-term well-being of welfare mothers depends on their gaining the basic education and employment-related skills needed to obtain jobs that pay a sustaining wage" (p. 195). The authors also claimed that policy reforms make it much more difficult for public assistance recipients (in particular, single mothers) to pursue higher education. More recently, Dave et al. (2012) found that welfare reform reduces the probability that adult women at risk of going on public assistance will enroll in college by 20 percent.

The most current executive order known as Reducing Poverty by Promoting Opportunity and Economic Mobility was published in 2018. This directive focuses on improving employment outcomes by addressing the challenges that some populations face in finding and maintaining employment in order "to move people to independence"(Section 2 (c) p. 19,542). Specifically, the document encourages federal and state public assistance agencies to enforce current work requirements and to propose additional stronger requirements (The White House, 2018).

Given the number of changes to the educational and public assistance systems over the past several decades, researchers have studied a variety of issues related to these policy changes. In particular, one strand of literature focuses on high school curriculums and the returns to education. Specifically, taking advanced courses in mathematics has been examined in relation to achievement outcomes such as test scores, high school graduation rates, college readiness, college entry and performance, college persistence, and labor market outcomes. However, although these outcome variables are related to the issue of public assistance reform, none of these studies looked directly at how taking more rigorous high school courses is related to income support participation. In this paper, the relationship between advanced mathematics course-taking and income support participation is examined by employing a survey that tracks students from high school through early adulthood. More specifically, this research seeks to examine if taking advanced math courses lowers the probability of income support receipt among American young adults. This secondary analysis provides a contribution to the literature by using an outcome variable that has not been directly examined in relation to advanced math course-taking in high school via empirical methods.

\section{Literature Review}

Many studies and reports discuss the importance of a rigorous high school curriculum and its relationship to student success (Byun et al., 2015). The link between advanced high school courses (in particular advanced math courses) and labor market outcomes or college entry and performance has also been studied to better understand achievement gaps based on gender, ethnicity, and socioeconomic status (Attewell \& Domina, 2008; Catsambis, 1994; Davenport et al., 1998; Klopfenstein, 2004; Riegle-Crumb, 2006). Given the data limitations and the fact that student course selection is dependent upon the available options and school requirements, most of these studies do not provide evidence of causal relationships. For example, using the National Longitudinal Study of 1972 (NLS72), 
Altonji (1995) employed an Instrumental Variables (IV) approach controlling for family background and found only a small, combined effect of an extra year of science, math, and foreign language. However, Altonji et al. (2012) concluded that "estimates for particular courses are affected by the interaction of biases in the coefficients on the curriculum variables and/or the control variables" (p. 199). Using the National Longitudinal Study of 1979 (NLSY79) and High School and Beyond (HSB), Levine and Zimmerman (1996) applied methods similar to Altonji (1995), and found that a year of math was associated with wage increases of $0.028-0.056 \log$ points for men and approximately 0.044 for women, but found that science courses have little to no effect for earnings in young adulthood. The authors also revealed that both math and science courses boost educational attainment and increased the probability that women would work in fields that involve more mathematical reasoning.

Rose and Betts (2004) used the senior cohort from the High School and Beyond (HSB) transcript data from 1980 and analyzed the return of high school math by examining wages nine years after graduation. One of the main contributions of this study was to incorporate math courses by level - vocational math, prealgebra, algebra/geometry, intermediate algebra, advanced algebra, and calculus, instead of aggregate credits. The authors controlled for demographic characteristics, family-background variables, math grade point average, and math test scores and found that advanced math courses substantially raise wage rates. They found no evidence of this result for advanced science courses.

A few studies employed a quasi-experimental design linking advanced math course taking in high school with labor force outcomes using wages as the dependent variable. For example, Joensen and Nielsen (2009) examined a pilot scheme used in select Denmark high schools from 1984 through 1987 to identify the causal effect of advanced high school math on labor market outcomes. The pilot scheme allowed students to take advanced math in combination with chemistry instead of physics only. The authors found that taking the advanced math course in combination with the advanced chemistry course was associated with increased earnings between $0.20-0.25$ percentage points depending on the particular model employed. The authors concluded that there is "clear evidence of a causal relationship between math and earnings for students who are induced to choose math after being exposed to the pilot scheme" (p. 171). In addition, Goodman (2012) used pooled HSB data and transcript data from the National Association for Educational Progress (NAEP) for the high school classes of 1987, 1990, and 1994, and took advantage of exogenous variation in state math course requirements implemented across different graduating classes to examine the causal effect of math course-taking on wages using a two-sample IV approach. The results of this study suggest that additional math courses have substantial value, significantly predicting improvements in wages, especially for Black males.

A related paper by Sosa (2016) used Local Average Treatment Effect (LATE) parameters that have a causal interpretation to examine the impact of mathematics course taking in high school on labor market outcomes. The author found that on average, each additional year of math courses during high school is associated with an increase of around $\$ 2,359$ in income at age 28 and around $\$ 2,135$ in income at age 29 using Instrumental Variable (IV) estimates. 
Research that focuses on the association between high school curriculum and college entry and performance is also abundant. For example, Adelman (2006) found that coursework above Algebra 2 significantly increases the likelihood of college completion. Specifically, the authors reported that graduation rates for a Bachelor's degree increased by about 16 percent if students were in the top 40 percent of their high school curriculum and also took math above Algebra 2 (Adelman, 2006).

Attewell and Domina (2008) considered both the equity concerns for disadvantaged groups accessing a rigorous high school curriculum as well as the ability of an intensive high school curriculum to yield payoffs in terms of college success. The authors found that students of lower socioeconomic status (whom were mostly Black and Hispanic in their study) have decreased access to a rigorous curriculum. In addition, the authors found that students who take a more intensive curriculum were more likely to go to college. Likewise, many researchers suggest that the positioning of students into classes of mixed ability, that is, de-tracking mathematics classrooms, increases opportunities for student learning (Burris et al., 2006). Using survey data, Boalar (2011) found that "students who worked in untracked groups had significantly moved up the social-class scale compared to their parents" (p. 10).

\section{Methods}

To examine the relationship between advanced math course-taking in high school and a student's subsequent participation in an income support program, a survey from the National Longitudinal Study of Adolescent to Adult Health (Add Health) was used. The Add Health survey is based upon a nationally representative sample of adolescents in grades 7-12 in the United States. The cohort of students in this study were initially given a questionnaire in 1994 and then later given the opportunity to participate in a series of inhome interviews in 1995, 1996, 2001-2002 and 2008. It should be noted that because the Add Health survey design used a clustered sample, this study employs Stata's survey estimation commands in conjunction with the proper sampling weights developed by Chen and Chantala (2014).

The dependent variable in this study, public assistance (PA), is a discrete binary response variable taking on a value of 0 or 1 . In the third wave of data which were collected in 2001-2002, the respondents were asked the following question pertaining to public assistance that is used in this study: "Are you currently getting AFDC, public assistance, or welfare? “

For the question above, $\mathrm{PA}=0$ if a respondent answered that they did not receive assistance, and PA $=1$ if a respondent answered that they did receive assistance. Since the primary aim of this study was to examine the effect of taking advanced math courses on subsequent receipt of public assistance, the variable of interest "Advanced Math" is considered at the following course levels: Algebra 1, Algebra 2, Precalculus, and Calculus. For each course level, advanced math course-taking is a dummy variable taking on a value of 1 if the respondent took the course during high school and 0 if they did not.

Although a regular probit model is often appropriate when the dependent variable is binary, in this case, the variable of interest (Advanced Math) is likely endogenous which 
requires the use of additional modelling techniques to account for selection bias. The endogeneity of Advanced Math is further complicated by the fact that it is also a binary variable. Thus, to test for endogeneity and appropriately estimate this model, a recursive bivariate probit model is used (Angrist \& Pischke, 2009; Greene, 1998, 2000).

Following Burnett (1997) who proposes a model of the joint determination of two binary choice variables, presence or absence of a gender economics course (y1) and presence or absence of a women's studies program (y2), the author obtains parameter estimates for two equations by formulating the following model:

$$
\begin{aligned}
& f_{2}\left(\mathrm{y}_{2}\right)=\Phi\left(\boldsymbol{\alpha}^{\prime} \mathbf{x}_{2}\right)^{\mathrm{y} 2} \times\left[1-\Phi\left(\boldsymbol{\alpha}^{\prime} \mathbf{x}_{2}\right)\right]^{1-\mathrm{y} 2} \\
& \mathrm{u}_{2}=\mathrm{y}_{2}-f_{2}\left(\mathrm{y}_{2}\right) \\
& f_{1}\left(\mathrm{y}_{1}\right)=\Phi\left(\boldsymbol{\beta}^{\prime} \mathbf{x}_{1}+\gamma \mathbf{u}_{2}\right]^{\mathrm{y} 1} \times\left[1-\Phi\left(\boldsymbol{\beta}^{\prime} \mathbf{x}_{1}+\gamma \mathrm{u}_{2}\right)\right]^{1-\mathrm{y} 1},
\end{aligned}
$$

where $\Phi(\bullet)$ is the distribution function of the standard normal distribution. Estimates of $\left[\boldsymbol{\beta}^{\prime}, \boldsymbol{\gamma}, \boldsymbol{\alpha}^{\prime}\right]$ were obtained by using "an iterated, seemingly unrelated Marquardt-Levenberg technique" (Burnett, 1997, p. 372). In this case the "residual" in the second equation is being used to alleviate the simultaneity of the women's studies variable in the gender economics equation. However, Greene (1998) pointed out that the two step procedure used by Burnett (1997) and as suggested by Rivers and Vuong (1988) is proposed for a probit model in which one or more of the right hand side variables are endogenous, but continuous. Greene (1998) stated that "Burnett's use of the residual in the second equation would be appropriate if WomStud were a continuous variable, but not a binary outcome" (p. 294). Greene (1998) also mentioned that "the Rivers and Vuong technique dictates conditional maximum likelihood estimation at the second step, not nonlinear least squares" (p. 294).

Following Greene's (1998) suggested improvements of Burnett's model, a twoequation system is used here to examine the relationship between public assistance participation and advanced math course-taking. The two equations are defined as follows (See Table 1 for definitions):

- $\quad$ Public Assistance $=f_{1}$ (Advanced Math, Gender, AssistanceBefore18, Age, Married, Race, WorkforPay10HRS, Child, MomCollege),

- Advanced Math $=f_{2}$ (Gender, Race, Teacher Trouble, MomCollege, AssistanceBefore18).

It should be noted that the demographic and background variables described were chosen based on data availability (what questions were asked in the survey) and previous literature focusing on the relationship between advanced mathematics courses and labor market outcomes. Table 1 provides summary statistics for the variables used in this model.

Given a sample size of 3,384 , Table 1 shows that approximately four percent of the survey respondents were receiving public assistance. This percentage is fairly consistent with the national average in the United States which was just over six percent between 2000 and 2001 (National Center for Education Statistics, 2011). In addition, approximately 89 percent of the respondents took Algebra 1, 65 percent took Algebra 2, 35 percent took Precalculus, and about 11 percent took Calculus. The sample was almost equally split by 
gender with 46 percent being male. About 73 percent of the respondents were Caucasian and 17 percent were married at the time of the survey. The average age of the respondents was 22 and about 13 percent had earned a bachelor's degree. The sample statistics also revealed that about 74 percent of the respondents worked for at least 10 hours a week and about 14 percent had lived in a household that received public assistance before they turned 18. Finally, about 32 percent of the respondents revealed that their mother had a college degree.

Table 1. Variable Definitions and Summary Statistics $(n=3,384)$

\begin{tabular}{l|l|r}
\hline Variable & Definitions & Mean (SD) \\
\hline Age & age (years) of respondent during the third wave of data collection & $21.77(1.77)$ \\
Gender & 1 if respondent is male, 0 otherwise & $0.46(0.50)$ \\
Race & 1 if respondent is white, 0 otherwise & $0.73(0.44)$ \\
Married & 1 if respondent is married, 0 otherwise & $0.17(0.38)$ \\
Child & number of children in respondent's household & $0.43(0.83)$ \\
WorkforPay10HRS & 1 if respondent works at least 10 hours a week, 0 otherwise & $0.74(0.44)$ \\
Bachelor & 1 if respondent has a bachelor's degree, 0 otherwise & $0.13(0.34)$ \\
Public Assistance & 1 if respondent is currently receiving income support in 2000-2001, & $0.04(0.19)$ \\
& 0 otherwise & \\
AssistanceBefore18 & 1 if anyone in respondent's household received public assistance & $0.14(0.35)$ \\
MomCollege & before respondent turned 18, 0 otherwise & \\
Teacher Trouble & 1 if respondent's mother is a college graduate, 0 otherwise & $0.32(0.47)$ \\
Algebra 1 & 1 if respondent claimed to have had trouble getting along with their & \\
Algebra 2 & 1 teachers, 0 otherwise & \\
Precalculus & 1 if respondent took at least Algebra 1 in high school, 0 otherwise & $0.89(0.31)$ \\
Calculus & 1 if respondent took at least Algebra 2 in high school, 0 otherwise & $0.65(0.48)$ \\
\hline
\end{tabular}

When considering the model's specification, Greene (1998) suggested that the estimators be written in simpler terms. Let

$\mathrm{y}_{1}=$ Public Assistance,

$\mathrm{x}_{1}=$ all variables on the right hand side of the first equation except Advanced

Math

$\mathrm{y}_{2}=$ Advanced Math,

$\mathrm{x}_{2}=$ all variables on the right hand side of the second equation.

The initial estimation of the Advanced Math $\left(\mathrm{y}_{2}\right)$ equation is done with the maximum likelihood probit analysis. In the second step, I use the predicted values from the Advanced Math equation which are the sample estimates of $\Phi\left(\alpha^{\prime} \mathbf{x}_{2}\right)$, (i.e., the sample estimates of $\left.\mathrm{E}\left[\mathrm{y}_{2} \mid \mathbf{x}_{2}\right]\right)$. The second step consists of maximum likelihood probit estimation of the $\mathrm{y}_{1}$ equation, with the right-hand side variables $\mathbf{x}_{1}$ and the sample estimates of $\mathrm{E}\left[\mathrm{y}_{2} \mid \mathbf{x}_{2}\right]$ or $\left[\Phi\left(\alpha^{\prime} \mathbf{x}_{2}\right)\right]$ as shown earlier. Using this two-step procedure provides consistent estimators 
and appropriate asymptotic standard errors (Greene, 1998). Given the relationships among joint, conditional, and marginal probabilities, the following is true:

$$
\begin{aligned}
\operatorname{Prob}\left[\mathrm{y}_{1}=1, \mathrm{y}_{2}=1\right] & =\operatorname{Prob}\left[\mathrm{y}_{1}=1 \mid \mathrm{y}_{2}=1\right] \times \operatorname{Prob}\left[\mathrm{y}_{2}=1\right] \\
& =\left\{\operatorname{BVN}\left(\mathrm{y}_{1}, \mathrm{y}_{2}=1\right) / \operatorname{Prob}\left[\mathrm{y}_{2}=1\right]\right\} \times \operatorname{Prob}\left[\mathrm{y}_{2}=1\right]
\end{aligned}
$$

where BVN is used to denote the cumulative distribution function of the bivariate normal distribution. After inserting the variables of the model, and introducing the two parameter vectors as developed from Burnett's equations, the end result is:

$\operatorname{Prob}\left[\mathrm{y}_{1}=1, \mathrm{y}_{2}=1\right]=\left[\operatorname{BVN}\left(\boldsymbol{\beta}^{\prime} \mathbf{x}_{1}+\gamma \mathrm{y}_{2}, \boldsymbol{\alpha}^{\prime} \mathbf{x}_{2}, \rho\right) / \Phi\left(\boldsymbol{\alpha}^{\prime} \mathbf{x}_{2}\right)\right] \times \Phi\left(\boldsymbol{\alpha}^{\prime} \mathbf{x}_{2}\right)$

(remember, $\left.\mathrm{y}_{2}=1\right)$, in which $\Phi\left(\boldsymbol{\alpha}^{\prime} \mathbf{x}_{2}\right)=\operatorname{Prob}\left[\mathrm{y}_{2}=1\right]$.

After rearranging and cancelling like terms in the numerator and denominator, the bivariate probability is $\operatorname{Prob}\left[\mathrm{y}_{1}=1, \mathrm{y}_{2}=1\right]=\operatorname{BVN}\left(\boldsymbol{\beta}^{\prime} \mathbf{x}_{1}+\gamma, \boldsymbol{\alpha}^{\prime} \mathbf{x}_{2}, \rho\right)$.

Greene (1998) showed that there are four cases for this bivariate probit model that can be constructed analogously to the first.

The remaining cases are as follows:

$$
\begin{aligned}
& \operatorname{Prob}\left[\mathrm{y}_{1}=0, \mathrm{y}_{2}=1\right]=\operatorname{BVN}\left(-\boldsymbol{\beta}^{\prime} \mathbf{x}_{1}-\gamma, \boldsymbol{\alpha}^{\prime} \mathbf{x}_{2},-\rho\right), \\
& \operatorname{Prob}\left[\mathrm{y}_{1}=1, \mathrm{y}_{2}=0\right]=\operatorname{BVN}\left(\boldsymbol{\beta}^{\prime} \mathbf{x}_{1}, \boldsymbol{\alpha}^{\prime} \mathbf{x}_{2},-\rho\right), \\
& \operatorname{Prob}\left[\mathrm{y}_{1}=0, \mathrm{y}_{2}=0\right]=\operatorname{BVN}\left(-\boldsymbol{\beta}^{\prime} \mathbf{x}_{1},-\boldsymbol{\alpha}^{\prime} \mathbf{x}_{2}, \rho\right) .
\end{aligned}
$$

According to Greene (1998), these are "the terms that enter the usual likelihood function for the bivariate probit model. The counterintuitive result is that in the bivariate probit model, unlike in the linear simultaneous equations model, if the two dependent variables are jointly determined, we just put each on the right-hand side of the other equation (or, in our case, one of them) and proceed as if there were no simultaneity problem" (p. 295).

\section{Results}

The maximum likelihood estimates of the four separate recursive bivariate probit models are presented in Table 2. Note that column 1 represents the model using Algebra 1 as the variable of interest, column 2 represents the model using Algebra 2 as the variable of interest, and columns 3 and 4 use Precalculus and Calculus as the variables of interest, respectively. Before analyzing the coefficient estimates, it should be noted that Knapp and Seaks (1998) show that a likelihood-ratio test of whether the correlation coefficient of the residuals $\rho$ (rho) is equal to zero can be used as a Hausman endogeneity test in biprobit models. More specifically, $\rho$ can be interpreted as the correlation between the unobservable explanatory variables of the two equations. As shown in Table 2, the null of no endogeneity is rejected in three out of four specifications. Thus, the recursive bivariate probit model is deemed appropriate and reliable for all cases except where Algebra 2 is the variable of interest. 
Table 2. Recursive Bivariate Probit Model Coefficient Estimates

\begin{tabular}{|c|c|c|c|c|}
\hline \multirow{2}{*}{ Public Assistance Equation } & \multicolumn{4}{|c|}{ Dependent Variable: Public Assistance } \\
\hline & & & & \\
\hline Algebra 1 & $-1.9626 * *(0.4890)$ & & & \\
\hline Algebra 2 & & $-1.3941 *(0.5484)$ & & \\
\hline Precalculus & & & $-1.8369 * *(0.3018)$ & \\
\hline Calculus & & & & $-2.0440 * *(0.2982)$ \\
\hline Gender & $-0.7528 * *(0.1508)$ & $-0.7415 * *(0.1402)$ & $-0.5948 * *(0.1421)$ & $-0.2948 *(0.1355)$ \\
\hline Race & $-0.0932(0.1189)$ & $-0.0408(0.1431)$ & $0.0790(0.1245)$ & $-0.0689(0.0896)$ \\
\hline Married & $0.0613(0.1319)$ & $0.0143(0.1305)$ & $-0.0045(0.1006)$ & $0.0599(0.0791)$ \\
\hline Work10hrs & $-0.3229 * *(0.0971)$ & $-0.3428 * *(0.1144)$ & $-0.2904 * *(0.1031)$ & $-0.2305 * *(0.0823)$ \\
\hline Age & $0.0330(0.0346)$ & $0.0255(0.0342)$ & $0.0265(0.0263)$ & $0.0369(0.0217)$ \\
\hline Child & $0.1927 * *(0.0474)$ & $0.1828 * *(0.0563)$ & $0.1615 * *(0.0486)$ & $0.1666 * *(0.0386)$ \\
\hline AssistanceBefore 18 & $0.1118(0.1288)$ & $0.1281(0.1629)$ & $-0.0480(0.1309)$ & $0.0103(0.1201)$ \\
\hline MomCollege & $-0.2477 *(0.1258)$ & $-0.1627(0.1380)$ & $-0.0290(0.1133)$ & $0.1328(0.1222)$ \\
\hline Bachelor & $-0.3763(0.2533)$ & -0.32490 .2248 & $0.3517(0.2247)$ & $0.3870 *(0.1622)$ \\
\hline Constant & $-0.2086(0.9142)$ & $-0.9973(0.7340)$ & $-1.2300 *(0.5520)$ & $-1.8915 * *(0.4957)$ \\
\hline \multicolumn{5}{|c|}{ Advanced Math Equation } \\
\hline Gender & $-0.3495 * *(0.0745)$ & $-0.2413 * *(0.0550)$ & $-0.1752 * *(0.0549)$ & $0.0895(0.0718)$ \\
\hline Race & $0.1621 *(0.0777)$ & $0.2319 * *(0.0640)$ & $0.3008 * *(0.0656)$ & $0.0164(0.0819)$ \\
\hline Assistancebefore 18 & $-0.4057 * *(0.0867)$ & $-0.3326 * *(0.0766)$ & $-0.2751 * *(0.0781)$ & $-0.2424 *(0.1160)$ \\
\hline MomCollege & $0.3493 * *(0.1066)$ & $0.3732 * *(0.0721)$ & $0.3573 * *(0.0562)$ & $0.4668 * *(0.0605)$ \\
\hline TeacherTrouble & $-0.4062 * *(0.0886)$ & $-0.3613 * *(0.0862)$ & $-0.3183 * *(0.0839)$ & $-0.3392 * *(0.1044)$ \\
\hline Bachelor & $1.10636 * *(0.1917)$ & $1.3564 * *(0.1174)$ & $1.0337 * *(0.0805)$ & $0.7315 * *(0.0864)$ \\
\hline Constant & $1.2856 * *(0.0815)$ & $0.1785 * *(0.0667)$ & $-0.7649 * *(0.0685)$ & $-1.6004 * *(0.0864)$ \\
\hline $\mathrm{n}$ & 3,384 & 3,384 & 3,384 & 3,384 \\
\hline $\mathrm{F}$ & 22.95 & 34.04 & 45.00 & 17.14 \\
\hline Rho & $0.7170^{*}$ & 0.5327 & $0.8337^{*}$ & $0.9821 *$ \\
\hline
\end{tabular}


Table 3. Average Marginal Effects for the Recursive Bivariate Probit Model

\begin{tabular}{|c|c|c|c|c|}
\hline \multirow{2}{*}{ Public Assistance Equation } & \multicolumn{4}{|c|}{ Dependent Variable: Public Assistance } \\
\hline & & & & \\
\hline Algebra 1 & $-0.4395 *(0.1990)$ & & & \\
\hline Algebra 2 & & $-0.2132(0.1891)$ & & \\
\hline Precalculus & & & $-0.4462 *(0.2089)$ & \\
\hline Calculus & & & & $-0.8165 * *(0.1534)$ \\
\hline Gender & $-0.0673 * *(0.0118)$ & $-0.0929 * *(0.0310)$ & $-0.1666 * *(0.0273)$ & $-0.1741(0.0967)$ \\
\hline Race & $-0.0118(0.0110)$ & $-0.0146(0.0148)$ & $-0.0362(0.0301)$ & $-0.0389(0.0389$ \\
\hline Married & $0.0060(0.0127)$ & $0.0020(0.0176)$ & $0.0015(0.0343)$ & $0.0279(0.0371)$ \\
\hline Work10hrs & $-0.0314 * *(0.0091)$ & $-0.0473 * *(0.0187)$ & $-0.0993 * *(0.0263)$ & $-0.1074(0.0555)$ \\
\hline Age & $0.0032(0.0035)$ & $0.0035(0.0055)$ & $0.0091(0.0101)$ & $0.0172 *(0.0080)$ \\
\hline Child & $0.0188 * *(0.0041)$ & $0.0252 * *(0.0081)$ & $0.0552 * *(0.0111)$ & $0.0776 * *(0.0302)$ \\
\hline AssistanceBefore18 & $0.0178(0.0110)$ & $0.0305(0.0162)$ & $0.0742 *(0.0294)$ & $0.1044(0.0728)$ \\
\hline MomCollege & $-0.0301 *(0.0133)$ & $-0.0368(0.0223)$ & $-0.0850 *(0.0353)$ & $-0.1298 *(0.0625)$ \\
\hline Bachelor & $-0.0555 *(0.0284)$ & $-0.0569(0.0680)$ & $-0.0969(0.0771)$ & $-0.1201(0.0719$ \\
\hline
\end{tabular}

Note: Standard errors are in parentheses and significance $* *=p .<.01, *=p .<.05$. 
When examining the Public Assistance equation, it should be noted that all four course levels were found to be negative and statistically significant. This implies that taking advanced math courses in high school is associated with a lower probability of needing income support shortly after graduation. In addition, Gender was also negative and statistically significant in all specifications suggesting that males were on average less likely to become recipients of public assistance. The Child variable was found to be positive and statistically significant, which says that having more children in the household is associated with an increased probability of the respondent participating in the income support system. MomCollege was also found to be negative and statistically significant, but only in the first specification of the model where Algebra 1 was used to represent "Advanced Math" courses. All variables in the Advanced Math equations were also statistically significant and had the expected sign in columns 1-3. In column 4, using Calculus as the variable of interest, Gender and Race were not statistically significant. Since the estimated coefficients do not quantify the influence of the explanatory variables on the probability that $y=1$, researchers often calculate the average marginal effects to better interpret the model. Thus, the coefficients in Table 3 represent the average marginal effects and specify the average change in probability of requiring public assistance. The interpretation of the independent variables are described below in terms of percentage points after multiplying by 100 .

Numerically, the strongest effect was exerted by the Advanced Math variables. Specifically, when calculating average marginal effects, the estimated coefficient for Algebra 1 is -0.4395 which implies that taking at least Algebra 1 in high school decreases the respondent's probability of requiring public assistance by 44.0 percentage points. Similarly, taking at least Algebra 2 in high school decreases the probability of receiving public assistance by approximately 21.3 percentage points, taking at least Precalculus decreases the probability of needing public assistance by 44.6 percentage points, and taking Calculus decreases the probability of needing public assistance by 81.7 percentage points.

Of the remaining control variables, Gender, WorkforPay10Hrs, Child, Age, MomCollege, and Bachelor are also found to have a statistically significant impact when considering the average marginal effects. For Gender, being male reduced the probability of needing public assistance between 29.5 and 75.3 percentage points, working at least 10 hours a week reduced the probability of needing public assistance between 23.1 and 34.3 percentage points, and an additional child in the household increased the probability of needing public assistance between 16.2 and 19.3 percentage points. Age and Bachelor were only statistically significant when considering the effect of taking Calculus on the probability of needing public assistance. In these cases, being older increased the probability of the respondent needing public assistance by 3.7 percentage points and having a Bachelor's degree decreased the probability of the respondent needing public assistance by 38.7 percentage points. MomCollege was only statistically significant when considering the effect of taking Algebra 1 on the probability of needing public assistance. In this case, if the respondent's mother is a college graduate, the probability of the respondent needing public assistance was reduced by 24.8 percentage points. 


\section{Discussion}

Moving people to financial independence is a key policy directive in the area of welfare reform in the United States. For decades, a work-first approach has been the main tenet for achieving this goal. However, one of the unintended consequences of this approach has been a decline in college attendance for those students at higher risk for income support dependency (Dave et al., 2012). With fewer at-risk students attending college, how can high school graduates find sustainable jobs that keep them from needing public assistance?

With an economy that increasingly values a strong quantitative and analytical background, one way is for school social workers to help ensure that students are taking courses in high school that promote these types of skills. For example, Algebra is likely the first subject in which students have an opportunity to develop logical thinking and analytical skills. More specifically, students in an Algebra course are often asked to make decisions based on given information which helps them to develop problem-solving abilities. Taking additional advanced courses in mathematics can serve to solidify and enhance the skills learned in previous courses, promoting retention and helping students to become more comfortable applying their skills to different situations.

Because disadvantaged students are less likely to have access to important information about curricular choices (Hassrick \& Schneider, 2009), it is also important for social workers working within school systems to provide additional guidance to students and their parents starting in the middle school years, when gateway course selection begins. Social workers can work directly with high school counselors and mathematics teachers to ensure that those students who are most at risk of being underserved are being educated about the importance of their mathematics course selections.

Another important role for school social workers is to help students understand how to take advantage of the skills they developed while taking advanced math courses. Because each student's situation is unique, the decision to pursue higher education or sustainable employment is often based upon many factors. The results of this study suggest that taking advanced courses in mathematics can reduce income support dependency and thus school social workers can help students understand how to best apply the skills they have developed. In some cases, encouraging the pursuit of higher education may be appropriate while in others pursuing sustainable employment will be the better option. Finally, in addition, Chavkin (1996) examined a pilot program called Partnership for Access to Higher Mathematics (PATH) that consisted of an innovative pre-algebra curriculum combined with social work services to students and families. The findings of this study revealed that "social work and mathematics within partnership programs can help students make academic gains" (p. 329). As Chavkin (1996) pointed out, many students who have been tracked out of advanced mathematics courses face a variety of "serious health, social, economic, and motivational problems that prevent them from attending class and completing assignments. No matter how much these students want to succeed, life's problems are overwhelming to them" (p. 327). In general, teaching social and emotional skills in schools has been shown to have positive effects in a variety of areas such as behavior, attitudes, mental health, and academic achievement (Durlak et al., 2011; Sklad et al., 2012). By focusing on "the whole student," social workers can help to resolve or 
mediate issues that occur outside of school, so that students have a better chance of success after high school by taking higher level mathematics courses.

While this study provides some initial evidence that taking advanced math courses lowers the probability of future public assistance use, certain limitations of the analysis should be acknowledged. First, it is not entirely clear whether the link between math courses and public assistance is causal or if it merely reflects unobservable variability in student characteristics such as innate ability and motivation. However, it is noteworthy to mention that taking advanced math courses continues to matter after controlling for proxies of student ability (Bachelor's degree) and family background (Mother's education and previous income support as a child). A second limitation is that the study is only generalizable to students who just recently graduated in 2000-2001. Because the question about public assistance was not available in later years, it is not clear how long the surveyed graduates received assistance. It is possible that in later years the respondents were able to find sustainable employment.

Future research that follows students beyond the first few years after graduation would provide a clearer and more robust analysis of the relationship between math courses and future income support. For example, Long et al. (2009) analyzed data on students enrolled in Florida's public schools and colleges and found that high school courses "contribute significantly to their college readiness, with the largest gains occurring at Algebra 2" (p. 25). In a subsequent study, Long et al. (2012) used propensity score matching to estimate the differences in outcomes for students who take a rigorous course in high school. The authors found that students taking a rigorous course in high school were 5 to 6 percentage points more likely to enroll in college, complete more college credits, earn higher grade point averages, and were more likely to earn a Bachelor's degree. In addition, future studies that examine more recent data can provide information on how education reform since 2000 has affected the need for public assistance and whether or not a college preparatory approach is moving more high school graduates to sustainable employment.

\section{Conclusion}

This paper contributes to the current literature on the effects of a rigorous high school curriculum and its relationship to student success by employing a unique outcome variable pertaining to subsequent receipt of public assistance. Because respondents who take advanced mathematics courses are likely to have other characteristics that would lead them to have better market outcomes and thus not require income assistance, a recursive bivariate probit model was employed to account for selection bias. In addition, a variety of demographic and background variables such as gender, race, marital status, age, employment status, college degree, mother's education, history of public assistance, and troubles in school were incorporated to help control for selection bias as well. The estimated coefficients and subsequent average marginal effects reveal that taking advanced math courses in high school is associated with a decreased probability of students receiving public assistance shortly after graduation. Given this finding, more studies using receipt of public assistance as an outcome variable are warranted. 
In particular, for the United States, income support reform efforts are often found to move public assistance recipients towards an employment track rather than toward higher education. Although the importance of requiring advanced math course-taking for students on a college-preparatory track is well-established, instilling critical thinking and problemsolving skills through advanced math course-taking could prove to be just as important for non-college bound students on their path to independence. Future research that examines the longer-term impact of taking advanced math courses for those students who choose the employment path will help determine if these math courses promote sustainable employment.

\section{References}

Adelman, C. (2006). The toolbox revisited: Paths to degree completion from high school through college. Department of Education. https://www2.ed.gov/rschstat/research/pubs/toolboxrevisit/toolbox.pdf

Altonji, J. G. (1995). The effects of high school curriculum on education and labour outcomes. The Journal of Human Resources, 30(3), 409-438.

Altonji, J. G., Blom, E., \& Meghir, C. (2012). Heterogeneity in human capital investments: High school curriculum, college major, and careers. Annual Review of Economics, 4(1), 185-223. https://doi.org/10.3386/w17985

Angrist, J., \& Pischke, J. S. (2009). Mostly harmless econometrics: An empiricist's companion. Princeton University Press. https://doi.org/10.1515/9781400829828

Attewell, P., \& Domina, T. (2008). Raising the bar: Curricular intensity and academic performance. Educational Evaluation and Policy Analysis, 30(1), 51-71. https://doi.org/10.3102/0162373707313409

Boalar, J. (2011). Changing students' lives through the de-tracking of urban mathematics classrooms. Journal of Urban Mathematics Education, 4(1), 7-14.

Brauner, S., \& Loprest, P. (1999). Where are they now? What states' studies of people who left welfare tell us. Washington, DC: Urban Institute. http://webarchive.urban.org/UploadedPDF/anf32.pdf

Burnett, N. (1997). Gender economics courses in liberal arts colleges. Journal of Economic Education, 28(Fall), 369-377. https://doi.org/10.2307/1183420

Burris, C., Heubert, J., \& Levin, H. (2006). Accelerating mathematics achievement using heterogeneous grouping. American Educational Research Journal, 43(1), 103-134. https://doi.org/10.3102/00028312043001105

Byun, S., Irvin, M.J., \& Bell, B. A. (2015). Advanced math course taking: Effects on math achievement and college enrollment. Journal of Experimental Education, 83(4), 439-468. https://doi.org/10.1080/00220973.2014.919570

Catsambis, S. (1994). The path to math: Gender and racial-ethnic differences in mathematics participation from middle school to high school. Sociology of Education, 67(3), 199-215. https://doi.org/10.2307/2112791 
Center on Budget and Policy Priorities. (2020, February 6). Policy brief: Temporary Assistance for Needy Families. https://www.cbpp.org/research/family-incomesupport/temporary-assistance-for-needy-families

Chavkin, N. (1996). Social work and mathematics: Strange bedfellows or productive partners? The Clearing House, 69(6), 327-329. https://doi.org/10.1080/00098655.1996.10114331

Chen, P., \& Chantala, K. (2014). Guidelines for analyzing Add Health data. Carolina Population Center University of North Carolina at Chapel Hill. http://cdr.lib.unc.edu/downloads/1v53k016h

Common Core State Standards Initiatives. (2020). About the standards. http://www.corestandards.org/about-the-standards/

Dave, D. M., Corman, H., \& Reichman, N. E. (2012). Effects of welfare reform. Journal of Labor Research, 33(2), 251-282. https://doi.org/10.1007/s12122-012-9130-4

Davenport, E. C., Jr., Davison, M. L., Kuang, H., Ding, S. Kim, S., \& Kwak, N. (1998). High school mathematics course-taking by gender and ethnicity. American Educational Research Journal, 35(3), 497-514. https://doi.org/10.3102/00028312035003497

Durlak, J. A., Weissberg, R. P., Dymnicki, A. B., Taylor, R.D., \& Schellinger, K. B. (2011). The impact of enhancing students' social and emotional learning: A meta-analysis of school-based universal interventions. Child Development, 82(1), 405-432. https://doi.org/10.1111/j.1467-8624.2010.01564.x

Goodman, J. (2012). The labor of division: Returns to compulsory math coursework. Faculty Research Working Paper Series. Harvard Kennedy School. https://doi.org/10.3386/w23063

Greenberg, M. (2001). Welfare reform and devolution: Looking back and forward. Brookings Institution Press. https://doi.org/10.2307/20080986

Greene, W. (1998). Gender economics courses in liberal arts colleges: Further Results. Journal of Economic Education, 29(4), 291-300. https://doi.org/10.1080/00220489809595921

Greene, W. (2000). Econometric analysis (4th ed.). Prentice Hall.

Hamilton, L. S., Stecher, B. M., \& Yuan, K. (2008). Standards-based reform in the United States: History, research, and future directions. RAND Corporation. https:/www.rand.org/content/dam/rand/pubs/reprints/2009/RAND_RP1384.pdf

Hassrick, E., \& Schneider, B. (2009). Parent surveillance in schools: A question of social class. American Journal of Education, 155(2), 195-225. https://doi.org/10.1086/595665

Hays, S. (2003). Flat broke with children. Oxford University Press.

Hotz, J. V., Imbens, G. W., \& Klerman, J. A. (2006). Evaluating the differential effects of alternative welfare-to-work training components: A reanalysis of the California GAIN program. Journal of Labor Economic, 24(3), 521-566. https://doi.org/10.3386/w11939 
Jacobs, J. A., \& Winslow, S. (2003). Welfare reform and enrollment in postsecondary education. The Annals of the American Academy, 586(1), 194-217.

Joensen, J., \& Nielsen, H. (2009). Is there a causal effect of high school math on labor market outcomes? Journal of Human Resources, 44(1), 171-198. https://doi.org/10.3368/jhr.44.1.171

K12Academics. (2004-2020). Education reform. https://www.k12academics.com/educationreform

Klopfenstein, K. (2004). Advanced placement: Do minorities have equal opportunity? Economics of Education Review, 23(2), 115-131. https://doi.org/10.1016/s02727757(03)00076-1

Knapp, L.G., \& Seaks, T.G. (1998). A Hausman Test for a dummy variable in probit. Applied Economics Letters, 5(5), 321-323.

Levine, P., \& Zimmerman, D. (1995). The benefit of additional high-school math and science classes for young men and women. Journal of Business \& Economic Statistics, 13(2), 137-149. https://doi.org/10.2307/1392368

Long, M. C., Iatarola, P., \& Conger, D. (2009). Explaining gaps in readiness for college-level math: The role of high school courses. Education Finance and Policy, 4(1), 1-33. https://doi.org/10.1162/edfp.2009.4.1.1

Long, M. C., Conger, D., \& Iatarola, P. (2012). Effects of high school course-taking on secondary and postsecondary success. American Educational Research Journal, 49(2), 285-322. https://doi.org/10.3102/0002831211431952

Loprest, P. (1999). Families who left welfare: Who are they and how are they doing? Urban Institute. http://webarchive.urban.org/UploadedPDF/discussion99-02.pdf

National Center for Education Statistics. (2011). Youth indicators 2011 America's youth: Transition to adulthood. https://nces.ed.gov/pubs2012/2012026/tables/table 32.asp

National Commission on Excellence in Education. (1983). A nation at risk. U.S. Government Printing Office. https://www.edreform.com/wpcontent/uploads/2013/02/A_Nation_At_Risk_1983.pdf

Personal Responsibility and Work Opportunity Reconciliation Act of 1996, Pub. L. No. 104193, 110 Stat. 2105.

Peterson, J., Song, X., \& Jones-DeWeever, A. (2002). Life after welfare reform: Low-income single parent families, pre-and post-TANF (No. D446). Institute for Women's Policy Research Publication. https://files.eric.ed.gov/fulltext/ED469527.pdf

Riegle-Crumb, C. (2006). The path through math: Course sequences and academic performance at the intersection of race/ethnicity and gender. American Journal of Education, 113(1), 1-17. https://doi.org/10.1086/506495

Rivers, D., \& Vuong, Q. (1988). Limited information estimators and exogeneity tests for simultaneous probit models. Journal of Econometrics, 39(November), 347-366. https://doi.org/10.1016/0304-4076(88)90063-2 
Rose, H., \& Betts, J. (2004). The effect of high school courses on earnings. Review of Economics and Statistics, 86(2), 497-513. https://doi.org/10.1162/003465304323031076

Sawhill I. V., \& Haskins, R. (2002). Welfare reform and the work support system. Policy Brief No. 17, Brookings Institution Press, Washington, DC. https://www.brookings.edu/research/welfare-reform-and-the-work-support-system/

Semuels, A. (2016, April 1). The End of Welfare as We Know It. America's once-robust safety net is no more. The Atlantic. https://www.theatlantic.com/business/archive/ 2016/04/the-end-of-welfare-as-we-know-it/476322/

Sklad, M., Diekstra, R., De Ritter, M., Ben, J., \& Gravestein, C. (2012). Effectiveness of school-based universal social, emotional, and behavioral programs: Do they enhance students' development in the area of skill, behavior, and adjustment? Psychology in the Schools, 49(9), 892-910. https://doi.org/10.1002/pits.21641

Sosa, A. (2016). Impact of mathematics course taking during high school on earnings: Evidence from shocks to teachers' supply. Working Paper, https://aefpweb.org/sites/ default/files/webform/41/AlfredoSosa coursetaking2016-03-01Draft3.pdf

Ujifusa, A. (2018, July 31). Donald Trump signs first major education policy bill of his presidency. Education Week. https://www.edweek.org/ew/articles/2018/07/31/donaldtrump-signs-career-technical-education-bill.html

United States Census Bureau. (2015, May 28). 21.3 percent of U.S. Population participates in government assistance programs each month. https:/www.census.gov/newsroom/pressreleases/2015/cb15-97.html

White House. (2018, April 10). Executive Order Reducing Poverty in America by Promoting Opportunity and Economic Mobility. Social Programs. https://www.whitehouse.gov/presidential-actions/executive-order-reducing-povertyamerica-promoting-opportunity-economic-mobility/

Author note: Address correspondence to Kerry Adzima, Department of Economics, Pennsylvania State University at Erie, 5101 Jordan Road., Black School of Business, Erie, PA, 16563. Email: kak38@psu.edu

Acknowledgement: Research questions were used from Add Health, a project directed by Kathleen Mullan Harris and designed by J. Richard Udry, Peter S. Bearman, and Kathleen Mullan Harris at the University of North Carolina at Chapel Hill and funded by grant P01HD31921 from the Eunice Kennedy Shriver National Institute of Child Health and Human Development, with cooperative funding from 23 other federal agencies and foundations. Special acknowledgment is due Ronald R. Rindfuss and Barbara Entwisle for assistance in the original design. Information on how to obtain the Add Health data files is available on the Add Health website (http://www.cpc.unc.edu/addhealth). No direct support was received from grant P01-HD31921 for this project. 